\title{
Kaolin and salicylic acid alleviate summer stress in rainfed olive orchards by modulation of distinct physiological and biochemical responses
}

\author{
Cátia Brito ${ }^{\mathrm{a}}$, Lia-Tânia Dinis ${ }^{\mathrm{a}}$, Ana Luzio ${ }^{\mathrm{a}}$, Ermelinda Silva ${ }^{\mathrm{a}}$, Alexandre Gonçalves ${ }^{\mathrm{a}}$, \\ Monica Meijón ${ }^{\mathrm{b}}$, Monica Escandón ${ }^{\mathrm{b}}$, Margarida Arrobas ${ }^{\mathrm{c}}$, Manuel Ângelo Rodrigues ${ }^{\mathrm{c}}$, \\ José Moutinho-Pereira ${ }^{\mathrm{a}}$, Carlos M. Correia ${ }^{\mathrm{a} \text {, }}$ \\ ${ }^{a}$ CITAB - Centre for the Research and Technology of Agro-Environmental and Biological Sciences, Universidade de Trás-os-Montes e Alto Douro, 5000-801 Vila Real, \\ Portugal \\ ${ }^{\mathrm{b}}$ Plant Physiology, Department B.O.S., Faculty of Biology, University of Oviedo, Oviedo, Asturias, Spain \\ ${ }^{\mathrm{c}}$ CIMO - Mountain Research Centre, Polytechnic Institute of Bragança, Bragança, Portugal
}

\section{A R T I C L E I N F O}

\section{Keywords:}

Adaptation strategies

Mineral nutrition

Photosynthesis

Phytohormones

Secondary metabolism

\begin{abstract}
A B S T R A C T
In a changing world, the search for new agronomic practices that help crops to maintain and/or increase yields and quality is a continuous challenge. We aim to evaluate kaolin (KL) and salicylic acid (SA) effectiveness as summer stress alleviating agents through physiological, biochemical and immunohistochemical analysis. Olive trees (Olea europaea L. cv. Cobrançosa) grown under rainfed conditions were sprayed with 5\% KL and $100 \mu \mathrm{M}$ $\mathrm{SA}$, at the beginning of summer, during two consecutive years. KL enhanced relative water content (RWC), stomatal conductance $\left(\mathrm{g}_{\mathrm{s}}\right)$ net photosynthesis $(\mathrm{A})$ and leaf indole-3-acetic acid (IAA) signal, and decreased leaf sclerophylly, secondary metabolites and non-structural carbohydrates accumulation and abscisic acid (ABA).The trees treated with SA showed changes on IAA and ABA dynamics, and an enhancement in RWC, $\mathrm{g}_{s}$, A, soluble proteins, and leaf $\mathrm{P}$ and $\mathrm{Mg}$ concentrations during the summer. Notably, KL and SA also allowed a faster restauration of the physiological functions during stress relief. In sum, KL and SA foliar sprays alleviated the negative effects induced by summer stress in olive trees performance, by modulation of distinct physiological and biochemical responses.
\end{abstract}

\section{Introduction}

In the current settings, olive trees (Olea europaea L.) growing under the typical Mediterranean semi-arid conditions are affected by multiple environmental constraint factors, and since the region is particularly vulnerable to climate change (IPCC, 2013), we may expect more severe summer stress. Although olive tree is well-adapted to harsh conditions, a considerable expense of energy resources is used in defense mechanisms, compromising plant growth and productivity (Fernández, 2014). Water deficit, commonly associated to heat and high irradiance stresses, impairs plant water status, drives stomatal closure, mesophyll compactness and photoinhibition, compromising photosynthetic capacity (Bacelar et al., 2004, 2006, 2007; Petridis et al., 2012). The continuous stress imposition induces oxidative damages and improves the investment in secondary metabolism, leading to reserves depletion (Bacelar et al., 2006, 2007; Mattos and Moretti, 2015; Petridis et al., 2012). Furthermore, the cross-talk between different phytohormones mediate a wide range of adaptative responses, as growth, development, nutrient allocation, and source/sink transitions (Peleg and Blumwald, 2011). Although abscisic acid (ABA) is the most studied stress-responsive hormone, the role of indole-3-acetic acid (IAA) during environmental stress is emerging (Peleg and Blumwald, 2011).

Global climate change might compromise the economic viability of the olive rainfed sector, leading to the abandonment of traditional groves, with devastating environmental consequences. In this sense, it is required the implementation of agronomic strategies in order to alleviate the adverse effects of summer stress. Accordingly, the foliar application of kaolin (KL) and salicylic acid (SA) has been considered short-term adaptations for that purpose. KL, once sprayed on leaf surface, leaves a white protective particle film after water evaporation, increasing the reflection of excess radiation (ultraviolet, visible and infrared radiations), reducing the risk of leaf and fruit damage from heat load accumulation and solar injury (Glenn et al., 2005). The KL use to mitigate the negative influence of summer stress in olive trees was already appraised by some studies that report positive effects in plant water status, photosynthetic responses and yield (Denaxa et al., 2012;

\footnotetext{
* Corresponding author.

E-mail address: ccorreia@utad.pt (C.M. Correia).
} 
Nanos, 2015; Roussos et al., 2010), although this effectiveness was dependent from stress level and genotype (Nanos, 2015; Roussos et al., 2010). Thus, it is important to fill the lack in the understanding of KL action mode by studying other induced plant responses. Meanwhile, SA is a signaling phytohormone with diverse regulatory roles in plant metabolism, such as the antioxidant defense system activation, secondary metabolites production, osmolytes synthesis modulation and optimization of mineral nutrients status (Khan et al., 2015). Moreover, SA appears to be a key molecule to maintain a proper balance between photosynthesis and growth (Rivas-San Vicente and Plasencia, 2011). However, the precise mechanisms by which SA induces plant tolerance against abiotic stresses remain unknown (Khan et al., 2015; Rivas-San Vicente and Plasencia, 2011). As far as we know, SA application to improve stress tolerance in olive trees was only described under freezing (Hashempour et al., 2014) and salinity (Aliniaeifard et al., 2016) conditions, where suitable concentrations of SA revealed to be effective. In sum, the influence of KL (Brillante et al., 2016; Nanos, 2015; Shellie and Glenn, 2008) and SA (Fayez and Bazaid, 2014; Kang et al., 2012; Nazar et al., 2015; Wang et al., 2014) on stress mitigation is not consensual, since it depends on several factors that act in isolation or in combination, including genotypes, growth stage, concentration, administration mode and environmental conditions. Therefore, we aim to test the effectiveness of KL and SA as summer stress alleviating products in rainfed olive orchards. For this, a deep analysis was accomplished, evaluating specifically KL and SA influence on leaf structure, plant water status, photosynthetic performance, primary and secondary metabolites fluctuations, foliar phytohormones distribution and plant nutritional status.

\section{Material and methods}

\subsection{Site description, cultural practices and plant material}

The experimental trial took place in Bragança, Northest Portugal, at Pinheiro Manso farm $\left(41^{\circ} 48^{\prime} \mathrm{N}, 6^{\circ} 44^{\prime} \mathrm{W}\right)$, during two consecutive growing seasons (2015 and 2016), on a 5-years-old rainfed olive orchard (cv. 'Cobrançosa') planted at $7 \times 6 \mathrm{~m}$. The orchard was planted late in 2010 and produced the first fruits in 2013. Year 2014 was the first year that olive yield was recorded. The climate is typically Mediterranean with some Atlantic influence. Under the Koppen-Geiger climate classification, Bragança is classified as Csb, a temperate climate with hot and dry summers and rainy winters (IPMA, 2017). Annual precipitation in 2015 was $419.4 \mathrm{~mm}$ and $707.1 \mathrm{~mm}$ in 2016, 34\% and $83 \%$ of it between January and May, respectively. The average air temperature and monthly precipitation recorded during the experimental period are shown in supplementary Fig. 1. At the beginning of the experiment, soil total organic carbon (C) was $25.6 \mathrm{~g} \mathrm{~kg}^{-1}$ (Incineration method), $\mathrm{pH}$ (soil:water, 1:2.5) was 5.8, extractable phosphorus (P) (Egner-Rhiem method) was $87.9 \mathrm{mg} \mathrm{kg}^{-1}$, extractable potassium (K) (Egner-Rhiem method) was $102 \mathrm{mg} \mathrm{kg}^{-1}$, extractable boron (B) (Azomethine method) was $0.5 \mathrm{mg} \mathrm{kg}^{-1}$, exchangeable calcium (Ca) (ammonium acetate method, $\mathrm{pH}$ 7) was $7.2 \mathrm{cmolc} \mathrm{kg}^{-1}$ and exchangeable magnesium ( $\mathrm{Mg}$ ) (ammonium acetate method, $\mathrm{pH}$ 7) was 2.2 cmolc $\mathrm{kg}^{-1}$. Soil fertilization consisted in the annual application (in the last week of March) of a compound NPK $\left(10 \% \mathrm{~N}, 10 \% \mathrm{P}_{2} \mathrm{O}_{5}, 10 \%\right.$ $\mathrm{K}_{2} \mathrm{O}$ ) fertilizer and borax $(11 \% \mathrm{~B})$. The fertilizers were localized in squares of $16(4 \times 4) \mathrm{m}^{2}(2 \mathrm{~m}$ distance from the trunk $)$ per tree. In these areas, the compound fertilizer was applied at a rate corresponding to $50 \mathrm{~kg} \mathrm{ha}^{-1}$ of $\mathrm{N}, \mathrm{P}_{2} \mathrm{O}_{5}$ and $\mathrm{K}_{2} \mathrm{O}$ and borax at a rate of $2 \mathrm{~kg} \mathrm{~B} \mathrm{ha}^{-1}$. The ground was managed with a non-selective herbicide (glyphosate, isopropylammonium salt, $360 \mathrm{~g} \mathrm{~L}^{-1}$ active ingredient) applied beneath the trees in the areas corresponding to the application of fertilizers and at a dose of $3 \mathrm{~L} \mathrm{ha}^{-1}$. The fertilizers were left on the ground without incorporation. The inter-rows were tilled once a year late in April. The trees were yearly subjected to light interventions of pruning and training in February.

\subsection{Treatments applied and monitoring}

The experiment comprises three treatments: control (C) trees, sprayed with distilled water; kaolin (KL), sprayed with an aqueous solution of KL (Surround ${ }^{\circledR}$ WP, Engelhard Corporation, Iselin, NJ), at the manufacturer recommended dosage of $5 \%(\mathrm{w} / \mathrm{v})$; and salicylic acid (SA), sprayed with an aqueous solution of $100 \mu \mathrm{M}$ SA (Sigma-Aldrich, St. Louis, USA), selected based on results of preliminary research. Each plant was treated with a mean volume of $500 \mathrm{~mL}$ of spraying solution. All spray applications were supplemented with $0.1 \%(\mathrm{v} / \mathrm{v})$ Tween 20 and conducted according to good efficacy practice standard operating procedures adjusted for agricultural experiments. The treatments were applied in the absence of wind in the morning of $30^{\text {th }}$ June 2015 and $23^{\text {th }}$ June 2016. A second application in the same days was done for KL trees to ensure the adhesion uniformity of kaolin clay particles to form the required film. The KL treatment was repeated in $27^{\text {th }}$ August 2016 after a heavy rain event. Each treatment included three replicates, completely randomized, with three trees of similar canopy size per plot, separated by a buffer line of trees.

All the physiological, structural, biochemical and immunohistochemical measurements done at leaf level were taken in healthy, full expanded and mature leaves. The leaf gas exchange, chlorophyll $a$ fluorescence and leaf relative water content measurements were taken periodically during the two years of the study $(n=9)$, while the samples for leaf histological analysis $(n=9)$, leaf and stem biochemical analyses $(n=9)$ and leaf IAA and ABA immunolocalization $(n=3)$ were collected only in 2016 , at the peak of stress, $22^{\text {th }}$ August. To determine the nutritional status of olive trees, a pool of leaf samples per plot was taken in July 2016, during summer, at endocarp sclerification, and in January 2017, during the winter resting period $(n=3)$. A schematic representation of the experiment procedure is presented in Fig. 1.

\subsection{Leaf water status and structural analysis}

Leaf samples, detached in a similar position, were immediately placed into air-tight containers and the following parameters were examined: fresh weigh (FW; g); fresh weigh at full turgor (TW; g), measured after immersion of leaf petioles in demineralized water for $48 \mathrm{~h}$ in the dark at $4{ }^{\circ} \mathrm{C}$; and dry weigh (DW; g), measured after drying in a force-draft oven at $60{ }^{\circ} \mathrm{C}$ to a constant weight. Further, was calculated the relative water content $(\mathrm{RWC}=(F W-D W) /(T W-D W) \times 100 ; \%)$.

For histological analysis, leaf sections were taken from the middle of the leaves, to avoid differential thickness along the leaf. Cut sections were dehydrated, cleared and embedded in paraffin. Four $\mu \mathrm{m}$ crosssections were obtained using a rotary microtome (Leica RM 2135, Germany) placed on slides and stained with toluidine blue. Leaf tissues thickness were measured in the leaf cross-sections using an inverted optical microscope (Olympus IX51 with the image analysis software Cell^A).

To make stomatal impressions, one or two coats of polish (colodium) were applied to the abaxial surface of each leaf, after peltate hairs were removed. The polish was then carefully peeled off and placed on a microscope slide (Bacelar et al., 2004).

\subsection{Leaf gas exchange and chlorophyll a fluorescence}

Leaf gas exchange measurements were performed using a portable IRGA (LCpro +, ADC, Hoddesdon, UK), operating in the open mode. Measurements were performed on cloudless days under natural irradiance and environmental conditions on sun exposed leaves. Net photosynthetic rate $\left(\mathrm{A}, \mu \mathrm{mol} \mathrm{CO} \mathrm{CO}^{-2} \mathrm{~s}^{-1}\right)$, stomatal conductance $\left(\mathrm{g}_{\mathrm{s}}, \mathrm{mmol}\right.$ $\mathrm{H}_{2} \mathrm{O} \mathrm{m}^{-2} \mathrm{~s}^{-1}$ ) and the ratio of intercellular to atmospheric $\mathrm{CO}_{2}$ concentration $\left(\mathrm{C}_{\mathrm{i}} / \mathrm{C}_{\mathrm{a}}\right)$ were estimated using the equations developed by von Caemmerer and Farquhar, (1981). Intrinsic water use efficiency was calculated as the ratio of $\mathrm{A} / \mathrm{g}_{\mathrm{s}}\left(\mu \mathrm{mol} \mathrm{mol}{ }^{-1}\right)$. 


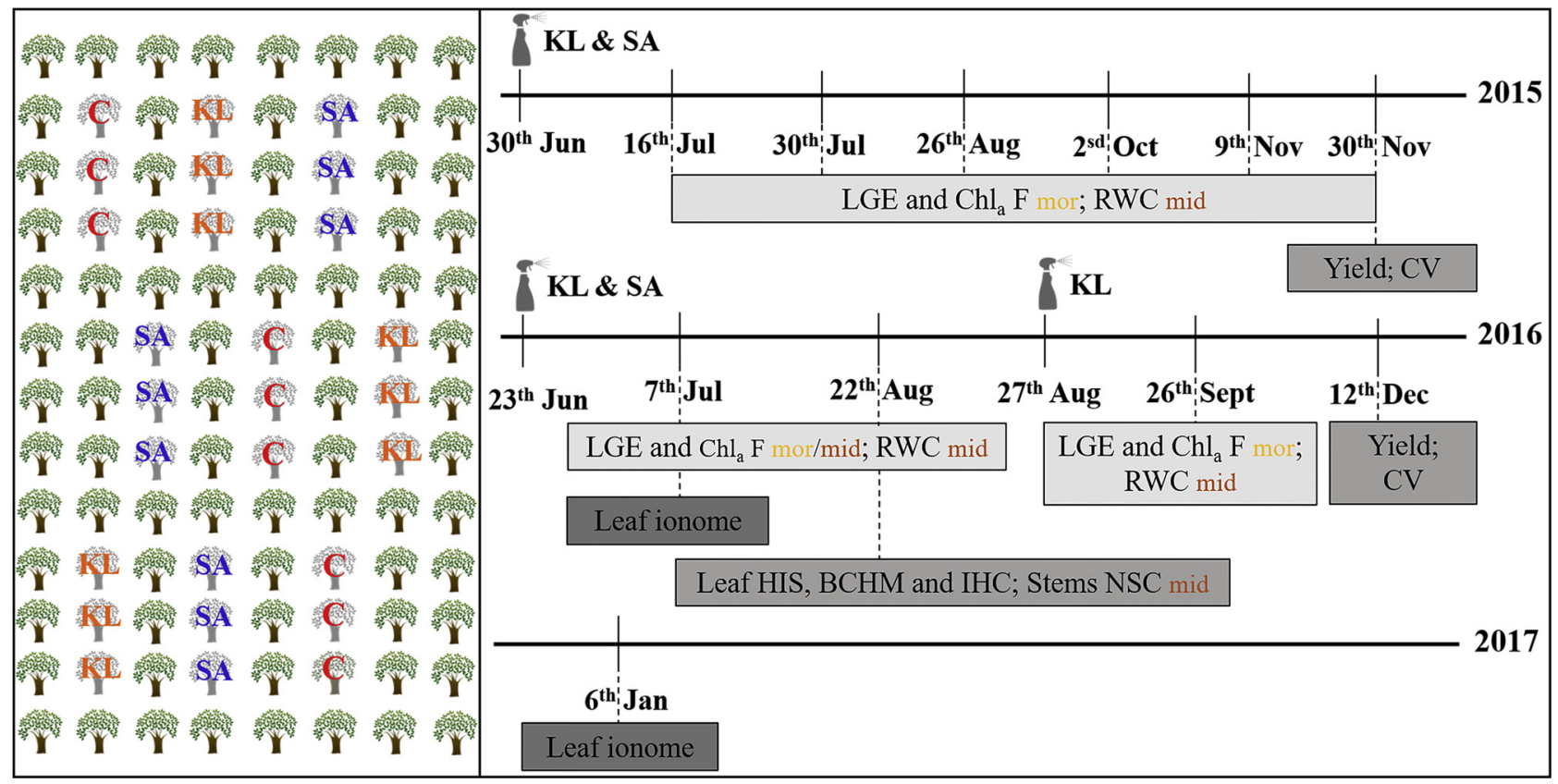

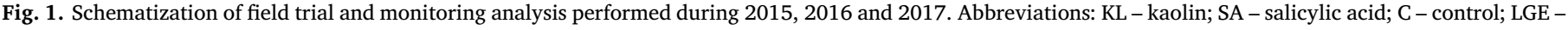

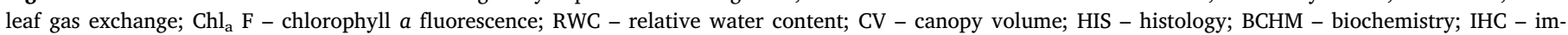
munohistochemistry; NSC - non-structural carbohydrates; mor - morning; mid -midday.

Chlorophyll $a$ fluorescence parameters were measured in vivo with a pulse-amplitude-modulated fluorometer (FMS 2, Hansatech Instruments, Norfolk, UK) on the same leaves and environmental conditions used for gas exchange measurements. Prior to the measurements, a small part of the leaves was dark-adapted for $30 \mathrm{~min}$ using dark-adapting leaf-clips. After this period, the minimal fluorescence $\left(\mathrm{F}_{\mathrm{o}}\right)$ was measured when all photosystem II (PSII) reaction centers are open using a low intensity pulsed measuring light source. The maximal fluorescence $\left(\mathrm{F}_{\mathrm{m}}\right)$ was measured when all PSII reactions centers are closed during a pulse saturating light $(0.7 \mathrm{~s}$ pulse of $15,000 \mu \mathrm{mol}$ photons $\mathrm{m}^{-2} \mathrm{~s}^{-1}$ of white light). The difference between these two levels $\left(F_{m}-F_{o}\right)$ is called variable fluorescence $\left(F_{v}\right)$. Maximum quantum efficiency of PSII was calculated as $\mathrm{F}_{\mathrm{v}} / \mathrm{F}_{\mathrm{m}}=\left(\mathrm{F}_{\mathrm{m}}-\mathrm{F}_{\mathrm{o}}\right) / \mathrm{F}_{\mathrm{m}}$ (Krause and Weis, 1991). Following $\mathrm{F}_{\mathrm{v}} / \mathrm{F}_{\mathrm{m}}$ estimation, after a $20 \mathrm{~s}$ exposure to actinic light $\left(1500 \mu \mathrm{mol} \mathrm{m}^{-2} \mathrm{~s}^{-1}\right)$, light-adapted steady-state fluorescence yield $\left(\mathrm{F}_{\mathrm{s}}\right)$ was averaged over $2.5 \mathrm{~s}$, followed by exposure to saturating light $\left(15,000 \mu \mathrm{mol} \mathrm{m}^{-2} \mathrm{~s}^{-1}\right)$ for $0.7 \mathrm{~s}$ to establish $\mathrm{F}_{\mathrm{m}}{ }_{\mathrm{m}}$. The sample was then shaded for $5 \mathrm{~s}$ with a far-red light source to determine $\mathrm{F}_{0}{ }_{0}$. From these measurements, several fluorescence attributes were calculated (Bilger and Schreiber, 1986; Genty et al., 1989): photochemical quenching $\left(\mathrm{qP}=\left(F_{m^{-}}-F_{s}\right) /\left(F_{m^{-}} F^{\prime}{ }_{0}\right)\right)$, non-photochemical quenching $\left(\mathrm{NPQ}=\left(F_{m^{-}}\right.\right.$ $\left.F_{m}^{\prime}\right) / F_{m}^{\prime}$ ) and efficiency of electron transport as a measure of the quantum effective efficiency of PSII ( $\Phi$ PSII $=\Delta F / F_{m}{ }_{m}=\left(F_{m}{ }^{\prime} F_{s}\right) / F_{m}{ }_{m}$ ). The apparent electron transport rate was estimated as ETR $\left(\mu \mathrm{mol} \mathrm{e}^{-} \mathrm{m}^{-}\right.$ $\left.{ }^{2} \mathrm{~s}^{-1}\right)=\left(\Delta F / F_{m}^{\prime}\right) \times P P F D \times 0.5 \times 0.84$, where PPFD is the photosynthetic photon flux density incident on the leaf, 0.5 is the factor that assumes equal distribution of energy between the two photosystems, and the leaf absorbance used was 0.84 , the most common value for $\mathrm{C}_{3}$ plants (Bilger and Schreiber, 1986).

\subsection{Biochemical assays}

Chlorophylls and carotenoids were extracted with $80 \%(\mathrm{v} / \mathrm{v})$ acetone. Chlorophyll $a\left(\mathrm{Chl}_{\mathrm{a}}\right)$, chlorophyll $b\left(\mathrm{Chl}_{\mathrm{b}}\right)$ and total chlorophyll $\left(\mathrm{Chl}_{(\mathrm{a}+\mathrm{b})}\right)$ were determined according to Arnon (1949) and Sesták et al., (1971) and total carotenoids (Car) according to Lichtenthaler (1987). Lycopene and $\beta$-carotene were extracted with acetone-hexane mixture (4:6) and determined according to Barros et al. (2011). Total soluble proteins (TSP) were quantified using the method of Bradford (1976), using bovine serum albumin (Sigma-Aldrich, St. Louis, USA) as a standard. Total phenolic compounds (TPC) were quantified following the Folin-Ciocalteu procedure (Singleton and Rossi, 1965), using gallic acid (Sigma-Aldrich, St. Louis, USA) as a standard. Flavonoids were determined according to Zhishen et al. (1999), using (+)-catechin (Sigma-Aldrich, St. Louis, USA) as a standard. Ascorbate was quantified using a method adapted from Klein and Perry (1982), using L-ascorbic acid (Fisher Chemical, UK) as a standard. Total antioxidant capacity (TAC) based on DPPH (2,2-Diphenyl-1-picrylhydrazyl)-free radical scavenging capacity was evaluated according to a method adapted from $\mathrm{Xu}$ and Chang (2007). Leaf methanolic extracts, and methanol for negative control, were mixed with DPPH methanolic solution $(0.1 \mathrm{mM})$ and left to stand for $30 \mathrm{~min}$ in dark at room temperature. The absorbance for the sample $\left(A_{\text {sample }}\right)$ and negative control $\left(A_{\text {control }}\right)$ was measured at $517 \mathrm{~nm}$ against methanol blank. The percent of DPPH radical reduction was calculated as follows $=100 \times\left(A_{\text {control }}-A_{\text {sample }}\right) /$ $A_{\text {control }}$. The free radical scavenging activity was expressed as $\mu \mathrm{M}$ of Trolox equivalents (Sigma-Aldrich, St. Louis, USA), TE = (\% DPPH radical reduction $/ a$ ), where $a$ is the slope of the standard curve $(\mathrm{y}=a \mathrm{x})$. Total soluble sugars (SS) were extracted according to Irigoyen et al. (1992), by heating the samples in $80 \%$ ethanol during $1 \mathrm{~h}$, at $80^{\circ} \mathrm{C}$. Then, the soluble fractions were separated from the solid fraction. Starch (St) was extracted by heating the same solid fraction in $30 \%$ perchloric acid during $1 \mathrm{~h}$, at $60^{\circ} \mathrm{C}$ according, to Osaki et al. (1991). Both SS and St concentrations were determined by the anthrone method, using glucose (Merck, Germany) as a standard.

\subsection{Immunodetection of $A B A$ and $I A A$}

For the immunodetection of indole-3-acetic acid (IAA) and abscisic acid (ABA), mature leaves of each treatment were fixed and processed according with Escandón et al. (2016). Propidium iodide was used as counterstain. Fluorescence, in both immunochemical essays, was visualized using a confocal microscope (Leica TCS-SP2-AOBS) connected to a workstation and the images were processed with Fiji Software (Schindelin et al., 2012). Negative controls in both immunochemical essays were obtained replacing the primary antibody by PBS (See 
supplementary Fig. 2).

\subsection{Leaf mineral analyses}

Leaves were collected from the middle of current season shoots of the four quadrants around the tree canopy. The samples were then oven-dried at $70{ }^{\circ} \mathrm{C}$ and ground. Tissue analyses were performed by Kjeldahl (N), colorimetry (B and P), flame emission spectrometry (K) and atomic absorption spectrophotometry ( $\mathrm{Ca}, \mathrm{Mg}, \mathrm{Cu}, \mathrm{Fe}, \mathrm{Zn}$, and $\mathrm{Mn}$ ) methods (Walinga et al., 1989).

\subsection{Statistical analysis}

The statistical analysis was performed using the statistical software program SPSS for Windows (v. 22). All data sets satisfied the assumptions of ANOVA based on homogeneity of variances and normality. In all parameters, data were analyzed one-way factorial ANOVA and the post hoc Tukey's test. Significant differences were considered for $P<$ 0.05. For statistical analysis of RWC and CVI arcsine transformation was performed in percentage data.

\section{Results}

\subsection{Leaf water status and leaf structure}

The influence of KL and SA on RWC was dependent on the seasonal period of the experiment and the analyzed year (Fig. 2a, b). In the first year (Fig. 2a), KL contributed to increase RWC in the first two analyzed dates, losing this capacity at the end of summer, while SA stands out in the middle of the summer season. On the second year (Fig. 2b), in August, both products contributed to increase RWC.

Leaf histological analysis revealed that $\mathrm{KL}$ induced thinner leaves, due to the reduced thickness of upper palisade parenquyma (UPP), lower epidermis (LE) and trichome layer (TL) (Table 1). As a result, a reduced palisade/spongy parenchyma (PP/SP) ratio was observed in KL leaves. Regarding SA plants, the leaves presented lower TL thickness than C plants. Both KL and SA contributed to increase the stomatal density (Table 1).

\subsection{Leaf gas exchange and chlorophyll a fluorescence}

In general, both KL and SA foliar sprays contributed to keep higher $A$ and $g_{s}$ in relation to C plants (Fig. 3). In 2015, an exception was observed in the first sampling date, as KL plants exhibited the lower A,
Table 1

Leaf tissues thickness $(\mu \mathrm{m})$ and stomatal density (stomatal number $\mathrm{mm}^{-2}$ ) of control (C), salicylic acid (SA) and kaolin (KL) plants. Total section (LT), upper cuticle (UC), upper epidermis (UE), upper palisade parenchyma (UPP), spongy parenchyma (SP), lower palisade parenchyma (LPP), lower epidermis (LE), palisade/ spongy parenchyma ratio (PP/SP) and trichome layer (TL).

\begin{tabular}{lllll}
\hline & C & SA & KL & P-value \\
\hline LT & $548.8 \pm 3.9^{\mathbf{a}}$ & $543.8 \pm 4.9^{\mathbf{a}}$ & $501.8 \pm 8.7^{\mathbf{b}}$ & $* * *$ \\
UC & $5.73 \pm 0.17$ & $6.41 \pm 0.33$ & $5.90 \pm 0.18$ & n.s. \\
UE & $18.00 \pm 0.61^{\mathbf{a b}}$ & $17.11 \pm 0.52^{\mathbf{b}}$ & $19.29 \pm 0.53^{\mathbf{a}}$ & $*$ \\
UPP & $224.5 \pm 5.0^{\mathbf{a}}$ & $231.4 \pm 3.4^{\mathbf{a}}$ & $193.8 \pm 5.3^{\mathbf{b}}$ & $* * *$ \\
SP & $220.1 \pm 4.8$ & $218.2 \pm 4.8$ & $214.5 \pm 4.2$ & n.s. \\
LPP & $29.51 \pm 0.85$ & $27.67 \pm 0.68$ & $27.20 \pm 0.65$ & n.s. \\
LE & $15.53 \pm 0.36^{\mathbf{a}}$ & $15.01 \pm 0.45^{\mathbf{a b}}$ & $13.96 \pm 0.36^{\mathbf{b}}$ & $*$ \\
PP/SP & $1.17 \pm 0.04^{\mathbf{a}}$ & $1.20 \pm 0.03^{\mathbf{a}}$ & $1.03 \pm 0.02^{\mathrm{b}}$ & $* *$ \\
TL & $36.65 \pm 1.43^{\mathbf{a}}$ & $28.40 \pm 1.92^{\mathbf{b}}$ & $26.51 \pm 1.11^{\mathbf{b}}$ & $* * *$ \\
Stomatal density & $565.5 \pm 13.9^{\mathbf{b}}$ & $744.6 \pm 27.4^{\mathbf{a}}$ & $683.7 \pm 16.6^{\mathbf{a}}$ & $* * *$
\end{tabular}

Values are means \pm SE. Different letters within a line demonstrate significant differences between treatments (n.s., not significant, ${ }^{*} \mathrm{P}<0.05,{ }^{*} \mathrm{P}<0.01$, $* * * \mathrm{P}<0.001)$.

while SA plants already exhibited higher A than C plants. Stomatal conductance followed a similar pattern than A, although no statistical differences were found among treatments on July $30^{\text {th }}$ and November $30^{\text {th }}$ (Fig. 3b). The $\mathrm{A} / \mathrm{g}_{\mathrm{s}}$ was not statistically affected by treatments (Fig. 3c), while regarding $\mathrm{C}_{\mathrm{i}} / \mathrm{C}_{\mathrm{a}}$, it was only observed a reduction with KL application on July $30^{\text {th }}$ (Fig. 3d). In 2016, it was evident the typical midday depression of A and $\mathrm{g}_{\mathrm{s}}$ in all treatments, particularly in August (Fig. 3e, f). Concerning the treatment effect, on July $7^{\text {th }}$ and September $26^{\text {th }}$, both KL and SA plants presented higher A than C plants, whereas on August $22^{\text {th }}$ only SA trees had superior A at midday (Fig. 3e). Stomatal conductance follows generally a pattern like A (Fig. 3f). A/g $/ g_{s}$ was significantly affected by treatments only on July $7^{\text {th }}$. At morning, KL plants exhibited the lower $\mathrm{A} / \mathrm{g}_{\mathrm{s}}$, while at midday period SA plants presented higher values than the other treatments (Fig. $3 \mathrm{~g}$ ). In the same way, $\mathrm{C}_{\mathrm{i}} / \mathrm{C}_{\mathrm{a}}$ ratio was only affected by the treatments on July $7^{\text {th }}$. At morning, KL plants exhibited the highest ratios, while at midday the lower ratio was observed in SA plants (Fig. 3h).

Regarding chlorophyll $a$ fluorescence analysis, in 2015 , only on $30^{\text {th }}$ July was observed a significant influence of the applied products. At that date, SA leaves exhibited higher ФPSII and ETR and lower NPQ than C plants (Fig. 4), whereas both KL and SA-sprayed leaves showed higher $\mathrm{qP}$ (Fig. 4g). Furthermore, in general, all determined variables decreased progressively until October and, drastically in November (Fig. 4). In 2016, at midday period of July $7^{\text {th }}$, KL plants had higher $F_{v} /$

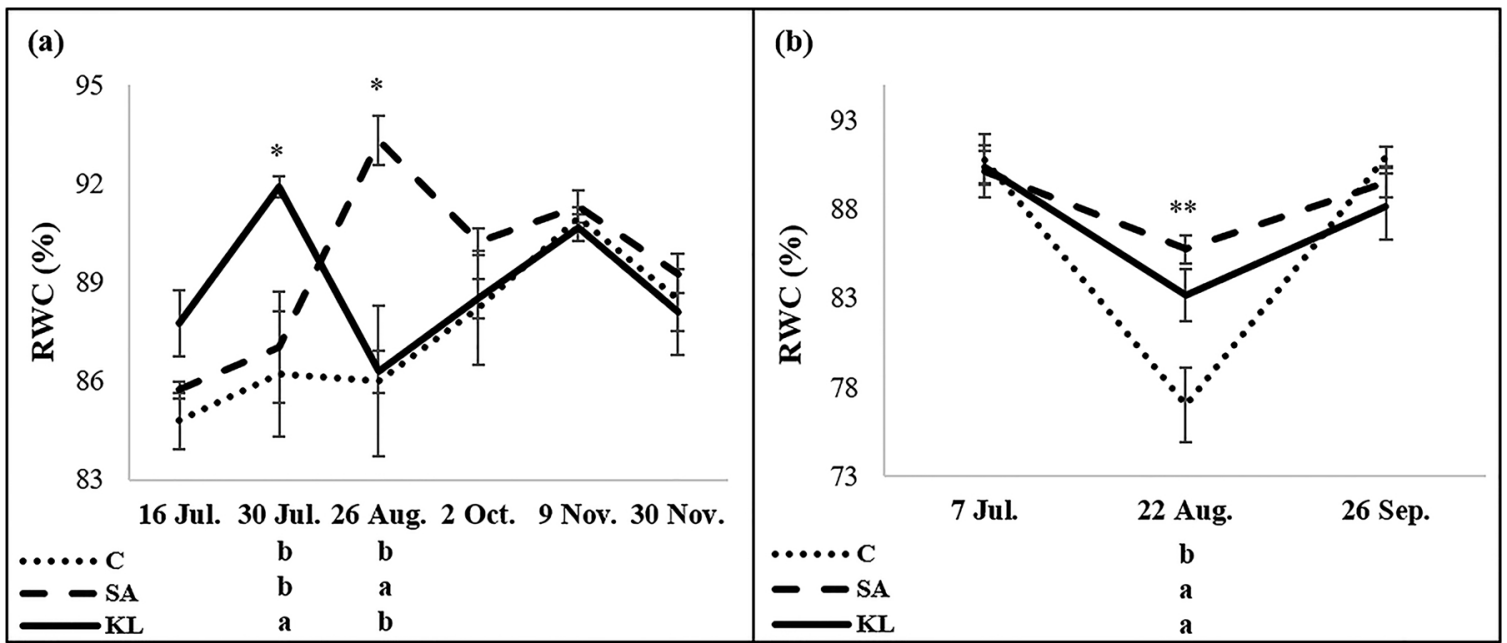

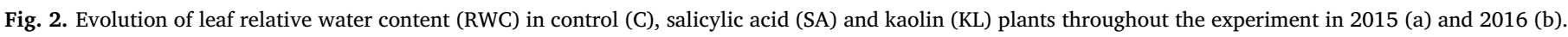
Values are means \pm SE. Different letters demonstrate significant differences between treatments in each analyzed date $(* \mathrm{P}<0.05$, $* * \mathrm{P}<0.01)$. 

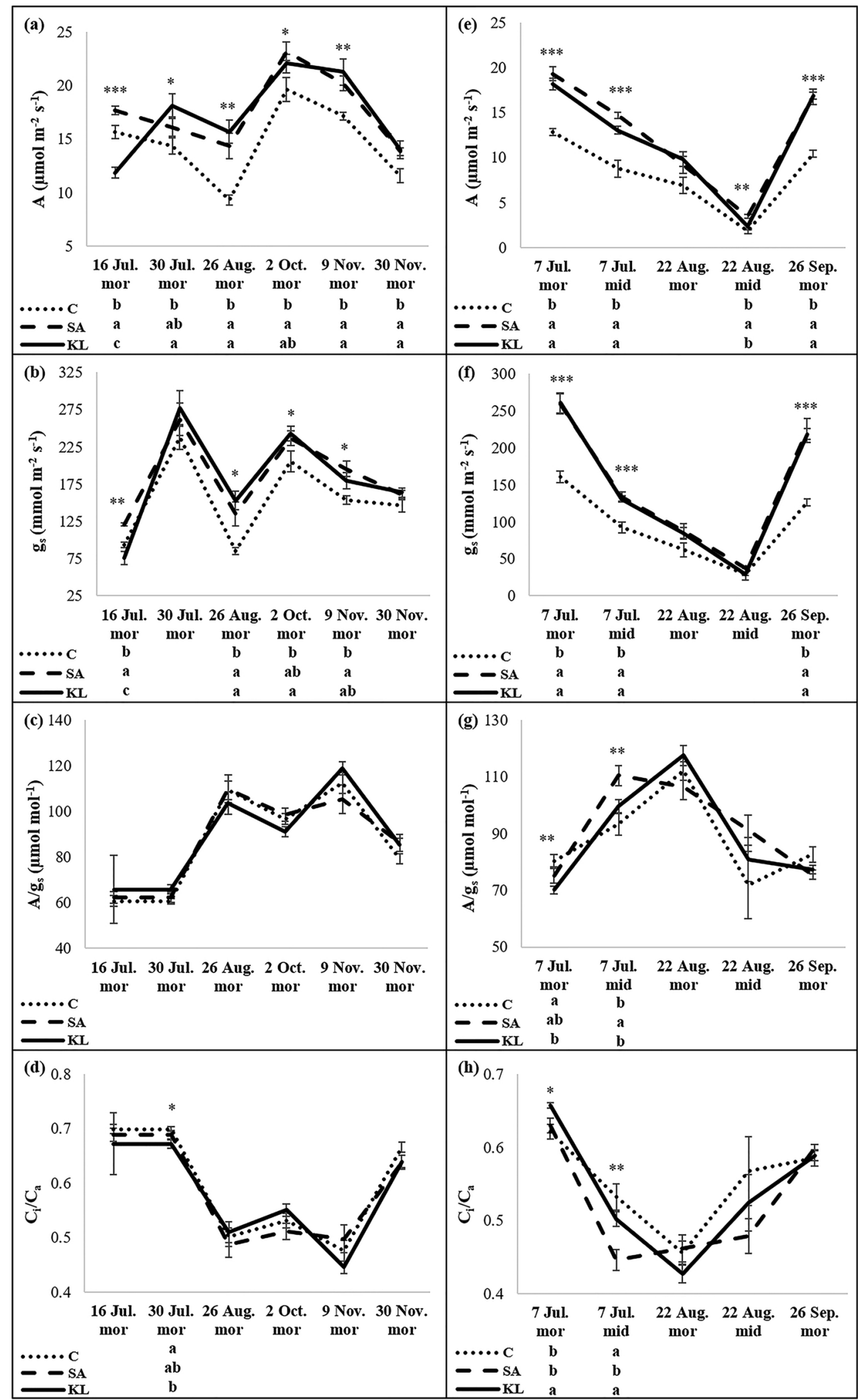

Fig. 3. Evolution of leaf gas exchange parameters in control (C), salicylic acid (SA) and kaolin (KL) plants throughout the experiment during the morning (mor) period of 2015 (A-D) and both morning (mor) and midday (mid) periods of 2016 (E-H). Net photosynthetic rate (A, a, e), stomatal conductance ( $\left.g_{s}, b, f\right)$, intrinsic water use efficiency $\left(A / g_{s}, c, g\right)$ and ratio of intercellular to atmospheric $\mathrm{CO}_{2}$ concentration $\left(\mathrm{C}_{\mathrm{i}} / \mathrm{C}_{\mathrm{a}}, \mathrm{d}, \mathrm{h}\right)$. Values are means $\pm \mathrm{SE}$. Different letters demonstrate significant differences between treatments in each analyzed date $\left({ }^{*} \mathrm{P}<0.05\right.$, $\left.{ }^{* *} \mathrm{P}<0.01,{ }^{* * *} \mathrm{P}<0.001\right)$. 


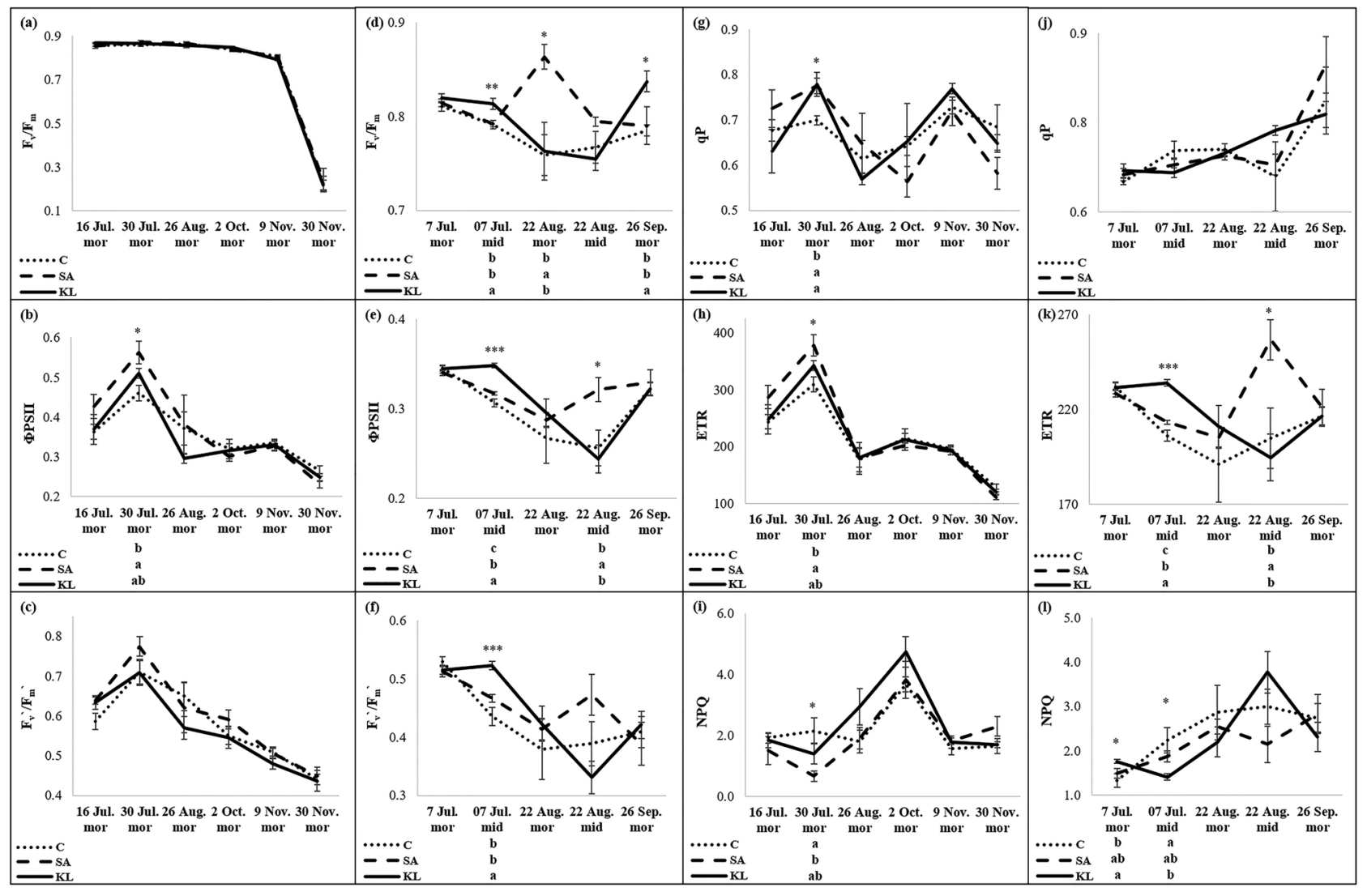

Fig. 4. Evolution of chlorophyll fluorescence variables in control (C), salicylic acid (SA) and kaolin (KL) plants throughout the experiment during the morning (mor) period of 2015 (A-C and G-I) and both morning (mor) and midday (mid) periods of 2016 (D-F and J-L). Maximum ( $\mathrm{F}_{\mathrm{v}} / \mathrm{F}_{\mathrm{m}}$, a, d) and effective ( $\Phi$ PSII, b, e) quantum efficiency of PSII, capture efficiency of excitation energy by open PSII reaction centers $\left(\mathrm{F}_{\mathrm{v}}{ }^{\prime} / \mathrm{F}^{\prime}{ }_{\mathrm{m}}, \mathrm{c}, \mathrm{f}\right)$, photochemical quenching $(\mathrm{qP}, \mathrm{g}, j)$, electron transport rate

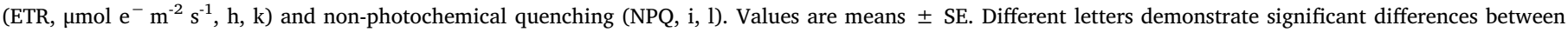
treatments in each analyzed date $\left(* \mathrm{P}<0.05, * * \mathrm{P}<0.01,{ }^{*} * * \mathrm{P}<0.001\right)$.

$\mathrm{F}_{\mathrm{m}}$, ФPSII, $\mathrm{F}_{\mathrm{v}} / \mathrm{F}_{\mathrm{m}}{ }_{\mathrm{m}}$ and ETR and lower NPQ than the other treatments (Fig. 4), whereas on August $22^{\text {th }}$, SA presented higher QPSII and ETR (Fig. 4e, k). Finally, on September $26^{\text {th }}$, KL leaves showed higher $F_{v} / F_{m}$ (Fig. 4g).

\subsection{Biochemical components}

Leaf biochemical analyses are summarized in Table 2. None of the applied products induced changes on $\mathrm{Chl}_{(\mathrm{a}+\mathrm{b})}$ and Car concentrations,

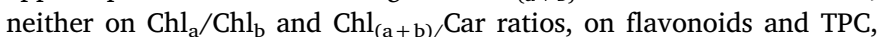
although a tendency for higher concentration of TPC in C plants. KL and SA lead to higher levels of lycopene and $\beta$-carotene, whereas TSP were enhanced only by SA. The ascorbate concentration was higher in C and $\mathrm{SA}$ than in KL plants. Regarding carbohydrates concentration, SS and St values followed the order $\mathrm{KL}<\mathrm{C}$ and $\mathrm{SA}$, and $\mathrm{SA}<\mathrm{KL}<\mathrm{C}$, respectively. The TAC based on DPPH radical scavenging was reduced in both KL and SA treatments. The accumulation of SS and St in stems followed the order $\mathrm{C} \leq \mathrm{SA} \leq \mathrm{KL}$ and $\mathrm{C}<\mathrm{SA}<\mathrm{KL}$, respectively.

\subsection{Immunodetection of $A B A$ and $I A A$}

The immunodetection of ABA andIAA revealed that both KL and SA induced differences in the signal intensity and distribution through the leaf tissues (Figures 5and 6). In general, ABA signal showed a uniform distribution throughout the leaf in all treatments. However, the intensity was higher in C and SA than in KL leaves (Fig. 5a, b, c). SA leaves showed an increased signal intensity in the main vascular tissues (Fig. 5b), compared to C (Fig. 5a). The IAA signal was substantially less evident than the ABA signal in all the analyzed leaves (Fig. 5d, e, f). In C
Table 2

Leaf and stem biochemical analyses of control (C), salicylic acid (SA) and kaolin (KL) plants. In leaves: total chlorophylls $\left(\mathrm{Chl}_{(\mathrm{a}+\mathrm{b})}, \mathrm{mg} \mathrm{g}^{-1} \mathrm{DW}\right.$ ), chlorophyll a/ $\mathrm{b}$ ratio $\left(\mathrm{Chl}_{\mathrm{a}} / \mathrm{Chl}_{\mathrm{b}}\right)$, total carotenoids (Car, $\left.\mathrm{mg} \mathrm{g}^{-1} \mathrm{DW}\right), \mathrm{Chl}_{(\mathrm{a}+\mathrm{b})} / \mathrm{Car}$ ratio, lycopene ( $\left.\mathrm{mg} \mathrm{g}^{-1} \mathrm{DW}\right), \beta$-carotene ( $\mathrm{mg} \mathrm{g}^{-1} \mathrm{DW}$ ), total soluble proteins (TSP, $\mathrm{mg} \mathrm{g}^{-1} \mathrm{DW}$ ), total phenolic compounds (TPC, $\mathrm{mg} \mathrm{g}^{-1} \mathrm{DW}$ ), flavonoids (mg $\mathrm{g}^{-1}$ DW), ascorbate ( $\mathrm{mg} \mathrm{g}^{-1} \mathrm{DW}$ ), total antioxidant activity (TAC, $\mu \mathrm{mol} \mathrm{g}^{-1}$ $\mathrm{DW})$, soluble sugars ( $\mathrm{SS}_{\text {leaf }}, \mathrm{mg} \mathrm{g}^{-1} \mathrm{DW}$ ) and starch (St $\left.\mathrm{Steaf}_{\text {, }} \mathrm{mg} \mathrm{g}^{-1} \mathrm{DW}\right)$ concentrations. In stems: soluble sugars ( $\left.\mathrm{SS}_{\text {Stems }}, \mathrm{mg} \mathrm{g}^{-1} \mathrm{DW}\right)$ and starch $\left(\mathrm{St}_{\text {Stems, }}\right.$, $\mathrm{mg} \mathrm{g}^{-1} \mathrm{DW}$ ) concentrations.

\begin{tabular}{|c|c|c|c|c|}
\hline & C & SA & KL & P-value \\
\hline $\mathrm{Chl}_{(\mathrm{a}+\mathrm{b})}$ & $2.80 \pm 0.05$ & $2.79 \pm 0.10$ & $2.65 \pm 0.05$ & n.s. \\
\hline $\mathrm{Chl}_{\mathrm{a}} / \mathrm{Chl}_{\mathrm{b}}$ & $3.05 \pm 0.03$ & $3.13 \pm 0.02$ & $3.13 \pm 0.04$ & n.s. \\
\hline Car & $0.605 \pm 0.008$ & $0.609 \pm 0.015$ & $0.579 \pm 0.008$ & n.s. \\
\hline $\mathrm{Chl}_{(\mathrm{a}+\mathrm{b})} / \mathrm{Car}$ & $4.63 \pm 0.036$ & $4.57 \pm 0.057$ & $4.58 \pm 0.045$ & n.s. \\
\hline Licopene & $0.294 \pm 0.011^{\mathrm{b}}$ & $0.352 \pm 0.008^{\mathrm{a}}$ & $0.337 \pm 0.005^{\mathrm{a}}$ & $* *$ \\
\hline$\beta$-Carotene & $0.151 \pm 0.007^{\mathbf{b}}$ & $0.179 \pm 0.006^{\mathrm{a}}$ & $0.173 \pm 0.003^{\mathrm{a}}$ & * \\
\hline TSP & $5.39 \pm 0.40^{\mathrm{b}}$ & $8.18 \pm 0.21^{\mathrm{a}}$ & $5.94 \pm 0.10^{\mathrm{b}}$ & $* * *$ \\
\hline TPC & $46.05 \pm 1.24$ & $43.24 \pm 0.59$ & $42.21 \pm 1.36$ & n.s. \\
\hline Flavonoids & $24.22 \pm 0.46$ & $24.04 \pm 1.09$ & $24.20 \pm 0.23$ & n.s. \\
\hline Ascorbate & $0.885 \pm 0.022^{\mathrm{a}}$ & $0.920 \pm 0.027^{\mathrm{a}}$ & $0.537 \pm 0.043^{\mathbf{b}}$ & $* * *$ \\
\hline TAC & $133.9 \pm 1.2^{\mathrm{a}}$ & $126.5 \pm 0.7^{\mathrm{b}}$ & $128.6 \pm 0.9^{\mathrm{b}}$ & $* * *$ \\
\hline $\mathrm{SS}_{\text {leaf }}$ & $134.0 \pm 4.6^{\mathbf{a}}$ & $121.3 \pm 2.9^{\mathrm{a}}$ & $94.3 \pm 4.9^{\mathrm{b}}$ & $* * *$ \\
\hline $\mathrm{St}_{\text {leaf }}$ & $67.20 \pm 3.20^{\mathrm{a}}$ & $49.14 \pm 1.96^{\mathrm{c}}$ & $58.05 \pm 3.10^{\mathbf{b}}$ & $* *$ \\
\hline $\mathrm{SS}_{\text {Stems }}$ & $63.37 \pm 2.00^{\mathrm{b}}$ & $66.80 \pm 1.31^{\mathrm{ab}}$ & $71.02 \pm 2.62^{\mathrm{a}}$ & * \\
\hline $\mathrm{St}_{\text {Stems }}$ & $40.80 \pm 2.00^{\mathrm{c}}$ & $59.32 \pm 1.31^{\mathrm{b}}$ & $71.26 \pm 2.81^{\mathrm{a}}$ & $* * *$ \\
\hline
\end{tabular}

Values are means \pm SE. Different letters within a line demonstrate significant differences between treatments (n.s., not significant, ${ }^{*} \mathrm{P}<0.05$, ${ }^{* *} \mathrm{P}<0.01$, $* * * \mathrm{P}<0.001)$. 

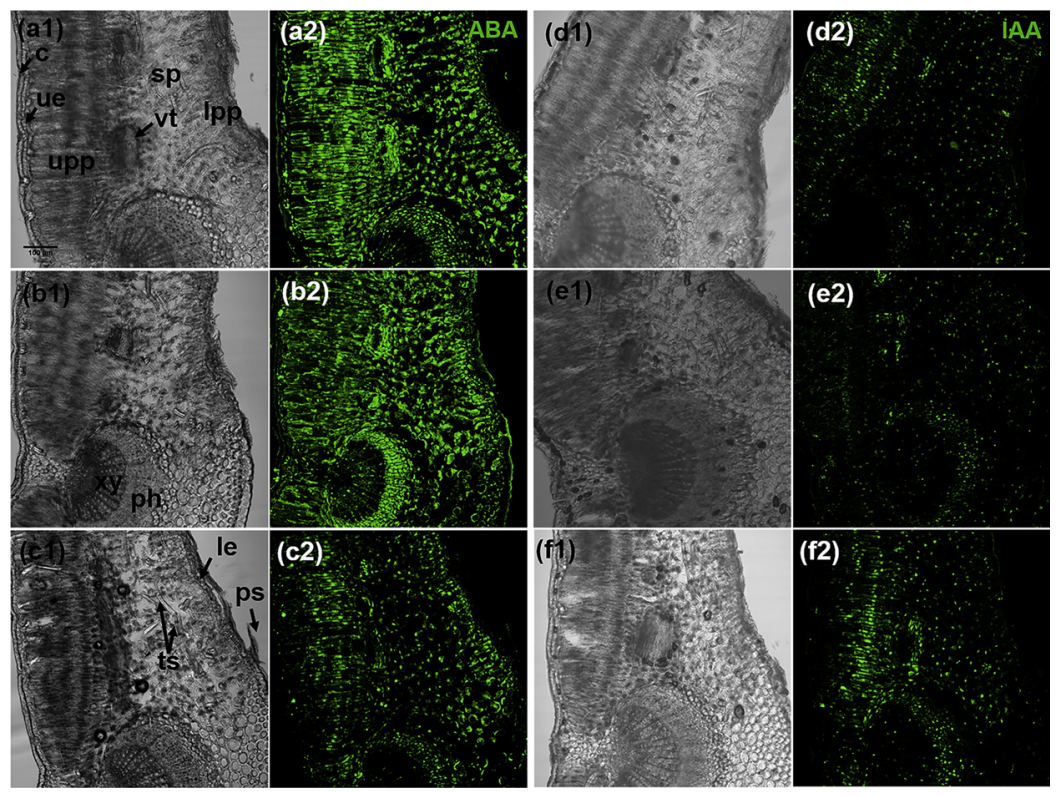

Fig. 5. Immunolocalization of $A B A(a-c)$ and IAA (d-f) in sections of olive leaves using confocal microscope $(20 \times)$. Differential interference contrast (a1, b1, c1, d1, e1, f1) and ABA (a2, b2, c2) and IAA (d2, e2, f2) signal. Control (C) plants (a, d), salicylic acid (SA) plants (b, e) and kaolin (KL) plants (c, f). Abbreviations: $\mathrm{c}=$ cuticle; $\mathrm{ue}=$ upper epidermis upp $=$ upper palisade parenchyma; $\mathrm{sp}=$ spongy parenchyma; $\mathrm{lpp}=$ lower palisade parenchyma; $\mathrm{xy}=\mathrm{xylem} ; \mathrm{ph}=$ phloem; $\mathrm{vt}=$ vascular tissue; $\mathrm{ts}=$ trichosclereids; le $=$ lower epidermis; $p s=$ peltate scales. A negative control was performed (bars $=100 \mu \mathrm{m}$ ).

leaves, it was possible to observe a uniform distribution of IAA signal across the leaf limb and an almost absence of signal in the main vascular tissues, especially in xylem (Fig. 5d). Both KL and SA leaves showed an increase in signal intensity in the main vascular tissues, especially in phloem (Fig. 5e, f), and KL plants also exhibited an increase in signal intensity in the UPP (Fig. 5f).

\subsection{Leaf mineral analyses}

The indicators of tree nutrient status are presented in Table 3. A great part of the evaluated minerals, namely $\mathrm{N}, \mathrm{P}, \mathrm{K}, \mathrm{B}, \mathrm{Cu}, \mathrm{Fe}$ and $\mathrm{Zn}$, were found in higher concentration in July than in January. At the same time, the applied products induced changes in the amounts of some minerals. In summer, $\mathrm{N}$ concentration followed the order $\mathrm{KL}<\mathrm{SA}=$ $\mathrm{C}, \mathrm{P}$ the order $\mathrm{KL}=\mathrm{C}<\mathrm{SA}, \mathrm{K}$ the order $\mathrm{KL} \leq \mathrm{C} \leq \mathrm{SA}, \mathrm{Mg}$ the order

Table 3

Leaf macronutrients (N, P, K, Ca, Mg, $\mathrm{g} \mathrm{kg}^{-1} \mathrm{DW}$ ) and micronutrients (B, Cu, $\mathrm{Fe}, \mathrm{Zn}, \mathrm{Mn}, \mathrm{mg} \mathrm{kg}^{-1} \mathrm{DW}$ ) of control (C), salicylic acid (SA) and kaolin (KL) plants in summer 2016 and winter 2017.

\begin{tabular}{|c|c|c|c|c|c|}
\hline & & C & SA & $\mathrm{KL}$ & P-value \\
\hline \multirow[t]{10}{*}{ Summer } & $\mathbf{N}$ & $22.53 \pm 0.43^{\mathrm{a}}$ & $21.93 \pm 0.03^{\mathrm{a}}$ & $20.80 \pm 0.06^{\mathbf{b}}$ & $* *$ \\
\hline & $\mathbf{P}$ & $1.27 \pm 0.14^{\mathrm{b}}$ & $1.85 \pm 0.09^{\mathrm{a}}$ & $1.23 \pm 0.03^{\mathrm{b}}$ & $* *$ \\
\hline & $\mathbf{K}$ & $13.30 \pm 2.2^{\mathrm{ab}}$ & $16.33 \pm 1.34^{\mathrm{a}}$ & $8.60 \pm 0.40^{b}$ & $*$ \\
\hline & $\mathrm{Ca}$ & $5.93 \pm 0.45$ & $7.12 \pm 0.48$ & $7.01 \pm 0.22$ & n.s. \\
\hline & Mg & $0.99 \pm 0.06^{\mathbf{b}}$ & $1.59 \pm 0.01^{\mathrm{a}}$ & $1.08 \pm 0.01^{b}$ & $* * *$ \\
\hline & B & $27.38 \pm 0.61$ & $25.92 \pm 0.32$ & $25.34 \pm 1.46$ & n.s. \\
\hline & $\mathrm{Cu}$ & $10.56 \pm 0.41^{\mathrm{a}}$ & $8.60 \pm 0.42^{\mathrm{ab}}$ & $7.67 \pm 0.65^{b}$ & $*$ \\
\hline & $\mathrm{Fe}$ & $111.62 \pm 18.7$ & $93.29 \pm 1.16$ & $86.24 \pm 7.52$ & n.s. \\
\hline & $\mathrm{Zn}$ & $36.25 \pm 1.59$ & $35.97 \pm 1.46$ & $38.44 \pm 8.41$ & n.s. \\
\hline & Mn & $65.08 \pm 1.19$ & $56.81 \pm 5.04$ & $67.56 \pm 3.32$ & n.s. \\
\hline \multirow[t]{10}{*}{ Winter } & $\mathbf{N}$ & $18.50 \pm 0.35$ & $19.90 \pm 0.91$ & $19.83 \pm 0.59$ & n.s. \\
\hline & $\mathbf{P}$ & $0.95 \pm 0.06$ & $0.86 \pm 0.04$ & $0.98 \pm 0.02$ & n.s. \\
\hline & $\mathbf{K}$ & $5.650 .15^{\mathbf{a}}$ & $4.44 \pm 0.15^{b}$ & $5.49 \pm 0.27^{\mathrm{a}}$ & $* *$ \\
\hline & $\mathrm{Ca}$ & $7.61 \pm 0.08$ & $9.99 \pm 1.47$ & $9.09 \pm 0.61$ & n.s. \\
\hline & Mg & $1.03 \pm 0.04$ & $1.26 \pm 0.18$ & $1.12 \pm 0.05$ & n.s. \\
\hline & B & $13.01 \pm 0.53$ & $13.11 \pm 0.55$ & $12.40 \pm 0.42$ & n.s. \\
\hline & $\mathrm{Cu}$ & $4.08 \pm 0.01^{c}$ & $4.12 \pm 0.01^{b}$ & $4.17 \pm 0.01^{\mathrm{a}}$ & $* *$ \\
\hline & $\mathrm{Fe}$ & $85.22 \pm 7.03$ & $83.49 \pm 7.98$ & $62.13 \pm 2.50$ & n.s. \\
\hline & $\mathrm{Zn}$ & $23.04 \pm 1.88$ & $21.90 \pm 1.32$ & $18.92 \pm 0.28$ & n.s. \\
\hline & Mn & $54.53 \pm 4.72$ & $59.23 \pm 5.32$ & $54.47 \pm 3.59$ & n.s. \\
\hline
\end{tabular}

Values are means \pm SE. Different letters within a line demonstrate significant differences between treatments (n.s., not significant, ${ }^{*} \mathrm{P}<0.05,{ }^{*} \mathrm{P}<0.01$, $* * * \mathrm{P}<0.001)$.
$\mathrm{C}=\mathrm{KL} \leq \mathrm{SA}$ and $\mathrm{Cu}$ the order $\mathrm{KL} \leq \mathrm{SA} \leq \mathrm{C}$. Meanwhile, in the winter, $\mathrm{K}$ concentration followed the order $\mathrm{SA}<\mathrm{KL}=\mathrm{C}$ and $\mathrm{Cu}$ the order $\mathrm{C}<\mathrm{SA}<\mathrm{KL}$.

\section{Discussion}

\subsection{KL and SA modulate leaf water status and structure}

The general improvement of leaf water status during the most stressful periods was corroborated by other studies with KL (Denaxa et al., 2012; Nanos, 2015) and SA (Kang et al., 2012; Nazar et al., 2015). The lower thickness of KL leaves, associated with the lower PP/ SP ratio, indicate a less compact arrangement of mesophyll cells (Bacelar et al., 2004), reflecting a reduced necessity to restrict water loss. Similar KL-induced leaf structural shade adaptations were described previously (Nanos, 2015; Segura-Monroy et al., 2015).The reduced TL in both KL and SA leaves also revealed a reduced necessity of protection, since trichomes are more abundant in leaves subjected to severe drought and high irradiance conditions (Bacelar et al., 2009; Savé et al., 2000).

The higher stomatal density in KL and SA leaves verified in the present study was also reported in response to $\mathrm{KL}$ in drought-stressed plants (Segura-Monroy et al., 2015) and in response to SA in saltstressed plants (Ma et al., 2017). This response is of great ecophysiological relevance because higher stomatal densities improve stomatal regulation capacity, increasing the ability to balance water loss with photosynthetic performance (Casson and Gray, 2008).

\subsection{KL and $S A$ application boosts photosynthetic activity}

The general positive influence of KL and SA on A and $g_{s}$ comes in agreement with previous studies in stressed plants treated with KL (Denaxa et al., 2012; Nanos, 2015) and SA (Nazar et al., 2015; Wang et al., 2014). Regarding KL, in 2015, the lowest A and $g_{s}$ recorded in recently sprayed plants, followed by a larger recovery, demonstrated that leaves need a period of acclimation to benefit from KL application. Moreover, it is possible to infer that the period depends on the environmental conditions, being shorter when they are severe, as in 2016. This happens because KL leaves reflect a significant part of the incident radiation, as demonstrated by Nanos (2015). In 2015, the influence of $\mathrm{KL}$ on A was mainly due to $\mathrm{g}_{\mathrm{s}}$ stimulation, but also to lower non-stomatal limitations, not related with photochemistry processes, judging 
by the relative variation of $\mathrm{g}_{\mathrm{s}}, \mathrm{A} / \mathrm{g}_{\mathrm{s}}, \mathrm{C}_{\mathrm{i}} / \mathrm{C}_{\mathrm{a}}$ and chlorophyll fluorescence variables. By reducing the heat load, this may reduce the leaf-to-air vapor pressure deficit ( $\mathrm{VPDl}_{\text {eaf-air }}$ ) (Jifon and Syvertsen, 2003; Rosati et al., 2006), and consequently the driving force for transpiration, promoting an increase of $g_{s}$ (Zhang et al., 2017). In 2016, the lower A of C plants on July $7^{\text {th }}$ was due to stomatal, but mainly to non-stomatal limitations considering the higher $\mathrm{C}_{\mathrm{i}} / \mathrm{C}_{\mathrm{a}}$ ratio recorded at midday period, in spite of the reduced $g_{s}$. In terms of photochemical processes, the higher $\mathrm{F}_{\mathrm{v}} / \mathrm{F}_{\mathrm{m}}$ and ETR of KL leaves indicate lower photoinhibitory damage (Maxwell and Johnson, 2000) and greater electron transport rate through PSII. Besides, although KL did not interfere with the proportion of open PSII reaction centers (e.g. similar qP), the higher ФPSII values indicate that the open PSII reaction centers captured the light absorbed by PSII antenna more efficiently (Baker, 2008). This response was certainly due to a reduced loss of excitation energy by thermal dissipation, which could compete with its transfer to PSII reaction centers, as evidenced by the higher and lower values of $\mathrm{F}_{\mathrm{v}}{ }_{\mathrm{v}} / \mathrm{F}_{\mathrm{m}}$ and NPQ, respectively (Baker, 2008). The positive effects of kaolin on the preservation of the photochemical processes was already described in other species (Dinis et al., 2016; Jifon and Syvertsen, 2003). Nonetheless, in the severest drought period of 2016, KL plants lose the effectiveness to maintain higher $g_{s}$ and A values, being this change related with the worsening of summer environmental conditions from 2015 to 2016. In agreement, the higher efficiency of photochemical processes recorded on July $7^{\text {th }}$ was also lost. Likewise, the loss of $\mathrm{KL}$ effectiveness in keeping $\mathrm{g}_{\mathrm{s}}$ and A with higher stress severity was documented previously (Nanos, 2015; Shellie and Glenn, 2008).

Regarding SA, the positive influence on A in 2015 was due to $g_{s}$ stimulation, but also to lower non-stomatal limitations, as previously pointed out to KL responses. In 2016, SA was the most effective product to decrease the midday depression of $\mathrm{A}$, a typical response of Mediterranean species (Bacelar et al., 2007). At midday period of August $22^{\text {th }}$, the absence of significant differences in $g_{s}$ and the higher $A$ recorded in SA plants indicate reduced non-stomatal limitations in relation to $\mathrm{KL}$ and $\mathrm{C}$ plants, which include a better performance of photochemical endpoints (ETR, ФPSII and $\mathrm{F}_{\mathrm{v}}{ }_{\mathrm{v}} / \mathrm{F}_{\mathrm{m}}$ ). The SA-induced protection of photosynthetic machinery under stress was also reported in other studies (Nazar et al., 2015; Wang et al., 2014).

Interestingly, the protection conferred by $\mathrm{KL}$ and SA during the summer period might allowed a faster recovery of $g_{s}$ and $A$ at the end of the summer and a better response in the autumn cold days of 2015 .

\section{3. $K L$ and $S A$ influence positively the foliar metabolites fluctuations}

In contradiction to our results, it is recurrent to find that both $\mathrm{KL}$ (Nanos, 2015; Segura-Monroy et al., 2015) and SA (Fayez and Bazaid, 2014; Wang et al., 2014) prevent chlorophylls degradation under stressful conditions. By other side, although the total carotenoids concentrations were not affected by the applied products, the relative composition was changed. The higher amounts of lycopene and $\beta$-carotene in sprayed trees may be an added value to those plants, as lycopene is the starting compound of various end group modifications that produces a large variety of carotenoids, such as $\beta$-carotene which display the ability to quench triplet chlorophyll and singlet oxygen (Domonkos et al., 2013). Meanwhile, apart from preventing TSP degradation, SA might increase its synthesis. In agreement, Kang et al. (2012) reported that SA application in droughted plants induces the expression of several proteins and Jalal et al. (2012) reported that SA alleviates the negative effect of drought on proteins concentrations, increasing its values and changing its patterns. Thus, the higher concentration of TSP might support the improvement of photosynthetic performance in SA plants in the severest drought period of 2016.

The tendency to higher accumulation of TPC in C leaves is somehow reflected in the higher DPPH radical scavenging activity, since phenolic compounds are known to overcome other antioxidants in the scavenging of this radical (Mattos and Moretti, 2015; Xu and Chang, 2007).
Such TPC response is common in stressed olive leaves (Bacelar et al., 2006; Petridis et al., 2012), and a similar reaction was found in drought stressed barley plants sprayed with SA (Fayez and Bazaid, 2014). On the other hand, the reduced accumulation of ascorbate in KL leaves suggests a reduced necessity of those plants to invest in secondary metabolism, while the high value in SA plants may be associated with its proposed action mode (Khan et al., 2015). Besides to directly scavenge ROS, it is also a substrate to ascorbate peroxidase that use it as specific electron donor to reduce $\mathrm{H}_{2} \mathrm{O}_{2}$ to $\mathrm{H}_{2} \mathrm{O}$ (Mattos and Moretti, 2015).

The higher accumulation of SS in C and SA leaves might be considered a protective mechanism to maintain cell homeostasis, a mechanism typically observed in droughted olive trees (Bacelar et al., 2006; Boussadia et al., 2013) and induced by SA application (El-Tayeb, 2005; Kang et al., 2012). On the other hand, the lower SS accumulation in KL leaves indicates that newly assimilated carbon was exported. In addition, the St depletion in both KL and SA plants also indicates the use of carbohydrates reserves, since St is an important storage carbohydrate that are usually mobilized in the form of SS (Rosa et al., 2009). As treated plants presented, in general, a better water status, we assume the preferential use of these carbon sources to growth and fruit development, instead of secondary metabolism investment. In fact, summer is a season of maximum carbohydrate demand for fruit growth and oil production (Bustan et al., 2011), and KL and SA plants exhibited the higher yields, averaging $97 \%$ and $72 \%$, respectively (Brito et al., 2018). Moreover, KL plants exhibited the higher canopy volume increase between November 2015 and December 2016 (83.0\% in KL plants against $59.5 \%$ in C plants). Meanwhile, as SA might induce the development of antioxidant responses (Khan et al., 2015), the higher St depletion in SA than in KL plants may be related to the activation of antioxidant defense mechanisms, as the increase in TSP and ascorbate.

During autumn and winter, when carbon sink demands are small, St and SS tends to accumulate (Bustan et al., 2011). Thus, the lower SS and mainly St accumulation in C stems, at the end of the summer, demonstrates that these plants had a reduced capacity to allocate reserves and/or transport carbohydrates, in a strictly association with the lower photosynthetic activity. In addition, the lower St concentration in $\mathrm{C}$ stems could also be explained by the conversion of St to sugars and the transportation of sugars for regrowth, fruit development and extra repair damages. Consequently, the higher carbohydrates accumulation in $\mathrm{KL}$ and SA stems can have a profoundly positive effect on trees performance in the following year.

\subsection{KL and SA induce changes in ABA and IAA dynamics}

Plant hormones signaling, particularly IAA and ABAis crucial for regulating plants adaptation capacity to different environment conditions (Peleg and Blumwald, 2011). The reduction of ABA signal in KL leaves reflects the better water status and higher $g_{s}$ of those plants. The higher ABA signal intensity in the main vascular tissues of SA leaves suggests its transport, highlighting SA signaling in ABA accumulation (Jesus et al., 2015; Shakirova et al., 2003). Furthermore, the intense signal in phloem may be related to the ABA involvement in assimilates flow and distribution regulation (Peng et al., 2003). On the other hand, the reduced IAA signal detection, when compared with ABA signal, reflects the main function of this phytohormone as growth promoter (Wani et al., 2016). The higher signal detection in the main vascular tissues of KL and SA leaves suggests IAA transport. Indeed, some studies have shown that drought stress influence local auxin concentration and distribution (Shen et al., 2010; Shojaie et al., 2015), allowing to maintain a balance between vegetative growth and survival (Shojaie et al., 2015). The higher signal detected in KL leaves, especially in UPP, might be a response to the reduced irradiation incidence due to kaolin particle film. In fact, shaded cotyledons and leaves had higher IAA synthesis (Zheng et al., 2016), and in response to unilateral light IAA moves to the shaded site of shoots (Fankhauser and Christie, 2015). On 
the other hand, it has been reported that SA application prevents drought and salinity induced IAA degradation (Fahad and Bano, 2012; Sakhabutdinova et al., 2003; Shakirova et al., 2003), justifying the higher IAA signal detection in SA than in C leaves. Moreover, this higher detection can also be associated with IAA function as stress signaling hormone in an early stage of stress (Jain and Khurana, 2009; Sharma et al., 2015). In fact, it was reported a markedly decrease of IAA with a transient increase during the initial stage of drought (Wang et al., 2008) and heat stress (Escandón et al., 2016).

\subsection{KL and SA modulate leaf minerals}

Despite the higher $g_{s}$ exhibited during summer, no positive effect of $\mathrm{KL}$ was recorded in leaf mineral status. In this case, a possible dilution effect may take place, since those plants exhibited the higher increase in canopy volume. Moreover, higher $g_{s}$ does not necessarily means an increase in water loss, since the expected reduction in $\mathrm{VPDl}_{\text {eaf-air }}$ with KL application (Jifon and Syvertsen, 2003; Rosati et al., 2006) may decrease the driving force for water movement (Zhang et al., 2017). As leaf $\mathrm{K}$ concentration in July was lower in KL than in SA plants, as $\mathrm{K}$ is involved in important biochemical and physiological processes, such as osmoregulation (Hu and Schmidhalter, 2005), and as KL plants had lower SS accumulation, it is possible to infer that KL plants had a reduced necessity to invest in osmotic adjustment. The tendency of SA plants to have higher mineral concentrations in summer was corroborated by other studies with stressed plants (El-Tayeb, 2005; Nazar et al., 2015; Yildirim et al., 2008), what could be, in part, promoted by the water movement associated with higher $\mathrm{g}_{\mathrm{s}}$. However, the observed significant differences among some elements indicate that plant minerals responses are complex, and might be related to changes in specific nutrient metabolic processes. Due to the higher yields of both $\mathrm{KL}$ and SA plants (Brito et al., 2018), it was expected higher translocation of $\mathrm{N}$ from leaves to fruits, as fruits are an important sink of $\mathrm{N}$ in the initial phase of growth (Rodrigues et al., 2012). However, this was not verified in SA leaves, probably due to the higher TSP concentration, since $\mathrm{N}$ is an important constituent of all amino acids and proteins. In winter, after the harvest period, the influence of the applied products was reduced, exhibiting SA leaves the lower concentration of K. Since olive fruits are important sinks of $\mathrm{K}$, may reaching $40 \%$ of total $\mathrm{K}$ (Rodrigues et al., 2012), higher amounts of $\mathrm{K}$ may have been exported to fruits.

\section{Conclusions}

The results of the present study revealed that KL and SA were effective in preventing the adverse effects of summer stress, contributing to better olive tree physiological performance. After the summer period, the attenuated negative effects induced by summer stress on KL and SA plants allowed a faster restauration of the physiological functions during the stress relief. Nevertheless, the effectiveness of each product was associated with distinct protective actions. KL contributed to keep a better water status possibly due to a specific microclimate created around the leaves, reducing water losses by transpiration, while it keeps high stomatal conductance. These effects contributed to increase the photosynthetic activity and the IAA immunodetected signal, to decrease $\mathrm{ABA}$ and to reduce the necessity to invest in leaf sclerophylly and secondary metabolism traits. Meanwhile, the protective action of SA was associated with the induction of some stress tolerance responses and the improvement in specific mineral status. Specifically, the maintenance of a better water status, stomatal conductance and photosynthetic machinery integrity, the increase in soluble proteins concentrations, in phytohormones immunodetected signal and in some non-enzymatic antioxidants contributed to alleviate summer stress.

\section{Acknowledgements}

The authors thank to Professor Maria da Conceição Santos for the critical review of final manuscript and helpful comments and suggestions.

Doctoral fellowship under the Doctoral Program "Agricultural Production Chains - from fork to farm" (PD/00122/2012) provided by the FCT-Portuguese Foundation for Science and Technology to C. Brito (PD/BD/ 52543/2014). The Spanish Ministry of Economy and Competitiveness supported to M. Meijón by Ramón y Cajal program (RYC-2014-14981). Institution CITAB, for its financial support through the European Investment Funds by FEDER/COMPETE/POCIOperational Competitiveness and Internationalization Program, under Project POCI-01-0145-FEDER-006958 and National Funds by FCT Portuguese Foundation for Science and Technology, under the project UID/AGR/04033/2013. INTERACT project - "Integrative Research in Environment, Agro-Chains and Technology", no. NORTE-01-0145FEDER-000017, in its lines of research entitled ISAC, co-financed by the European Regional Development Fund (ERDF) through NORTE 2020 (North Regional Operational Program 2014/2020).

\section{Appendix A. Supplementary data}

Supplementary material related to this article can be found, in the online version, at doi:https://doi.org/10.1016/j.scienta.2018.10.059.

\section{References}

Aliniaeifard, S., Hajilou, J., Tabatabaei, S.J., 2016. Photosynthetic and growth responses of olive to proline and salicylic acid under salinity condition. Not. Bot. Horti Agrobot. Cluj. 44, 579-585. https://doi.org/10.15835/nbha44210413.

Arnon, D.I., 1949. Copper enzymes in isolated chloroplasts. Polyphenoloxidase in Beta vulgaris. Plant Physiol. 24, 1-15. https://doi.org/10.1104/pp.24.1.1.

Bacelar, E.A., Correia, C.M., Moutinho-Pereira, J.M., Goncalves, B.C., Lopes, J.I., TorresPereira, J.M., 2004. Sclerophylly and leaf anatomical traits of five field-grown olive cultivars growing under drought conditions. Tree Physiol. 24, 233-239. https://doi. org/10.1093/treephys/24.2.233.

Bacelar, E.A., Moutinho-Pereira, J.M., Gonçalves, B.C., Lopes, J.I., Correia, C.M., 2009. Physiological responses of different olive genotypes to drought conditions. Acta Physiol. Plant. 31, 611-621. https://doi.org/10.1007/s11738-009-0272-9.

Bacelar, E.A., Santos, D.L., Moutinho-Pereira, J.M., Gonçalves, B.C., Ferreira, H.F., Correia, C.M., 2006. Immediate responses and adaptative strategies of three olive cultivars under contrasting water availability regimes: changes on structure and chemical composition of foliage and oxidative damage. Plant Sci. 170, 596-605. https://doi.org/10.1016/j.plantsci.2005.10.014.

Bacelar, E.A., Santos, D.L., Moutinho-Pereira, J.M., Lopes, J.I., Gonçalves, B.C., Ferreira, T.C., Correia, C.M., 2007. Physiological behaviour, oxidative damage and antioxidative protection of olive trees grown under different irrigation regimes. Plant Soil 292, 1-12. https://doi.org/10.1007/s11104-006-9088-1.

Baker, N.R., 2008. Chlorophyll fluorescence: a probe of photosynthesis in vivo. Ann. Rev. Plant Biol. 59, 89-113. https://doi.org/10.1146/annurev.arplant.59.032607. 092759.

Barros, L., Cabrita, L., Boas, M.V., Carvalho, A.M., Ferreira, I.C.F.R., 2011. Chemical, biochemical and electrochemical assays to evaluate phytochemicals and antioxidant activity of wild plants. Food Chem. 127, 1600-1608. https://doi.org/10.1016/j. foodchem.2011.02.024.

Bilger, W., Schreiber, U., 1986. Energy-dependent quenching of dark-level chlorophyll fluorescence in intact leaves. Photosyn. Res. 10, 303-308. https://doi.org/10.1007/ BF00118295.

Boussadia, O., Bchir, A., Steppe, K., Van Labeke, M.-C., Lemeur, R., Braham, M., 2013. Active and passive osmotic adjustment in olive tree leaves during drought stress. Eur. Sci. J. 9, 1857-7881.

Bradford, M.M., 1976. A rapid and sensitive method for the quantitation of microgram quantities of protein utilizing the principle of protein-dye binding. Anal. Biochem. 72, 248-254. https://doi.org/10.1016/0003-2697(76)90527-3.

Brillante, L., Belfiore, N., Gaiotti, F., Lovat, L., Sansone, L., Poni, S., Tomasi, D., 2016. Comparing kaolin and pinolene to improve sustainable grapevine production during drought. PLoS One 11, e0156631. https://doi.org/10.1371/journal.pone.0156631.

Brito, C., Dinis, L.-T., Silva, E., Gonçalves, A., Matos, C., Rodrigues, M.A., MoutinhoPereira, J., Barros, A., Correia, C., 2018. Kaolin and salicylic acid foliar application modulate yield, quality and phytochemical composition of olive pulp and oil from rainfed trees. Sci. Hortic. 237, 176-183. https://doi.org/10.1016/j.scienta.2018.04. 019.

Bustan, A., Avni, A., Lavee, S., Zipori, I., Yeselson, Y., Schaffer, A.A., Riov, J., Dag, A., 2011. Role of carbohydrate reserves in yield production of intensively cultivated oil olive (Olea europaea L.) trees. Tree Physiol. 31, 519-530. https://doi.org/10.1093/ treephys/tpr036. 
Casson, S., Gray, J.E., 2008. Influence of environmental factors on stomatal development. New Phytol. 178, 9-23. https://doi.org/10.1111/j.1469-8137.2007.02351.x.

Denaxa, N.-K., Roussos, P.A., Damvakaris, T., Stournaras, V., 2012. Comparative effects of exogenous glycine betaine, kaolin clay particles and Ambiol on photosynthesis, leaf sclerophylly indexes and heat load of olive cv. Chondrolia Chalkidikis under drought. Sci. Hortic. 137, 87-94. https://doi.org/10.1016/j.scienta.2012.01.012.

Dinis, L.-T., Ferreira, H., Pinto, G., Bernardo, S., Correia, C.M., Moutinho-Pereira, J., 2016. Kaolin-based, foliar reflective film protects photosystem II structure and function in grapevine leaves exposed to heat and high solar radiation. Photosynthetica 54, 47-55. https://doi.org/10.1007/s11099-015-0156-8.

Domonkos, I., Kis, M., Gombos, Z., Ughy, B., 2013. Carotenoids, versatile components of oxygenic photosynthesis. Prog. Lipid Res. 52, 539-561. https://doi.org/10.1016/j. plipres.2013.07.001.

El-Tayeb, M.A., 2005. Response of barley grains to the interactive effect of salinity and salicylic acid. Plant Growth Regul. 45, 215-224. https://doi.org/10.1007/s10725005-4928-1.

Escandón, M., Cañal, M.J., Pascual, J., Pinto, G., Correia, B., Amaral, J., Meijón, M., 2016. Integrated physiological and hormonal profile of heat-induced thermotolerance in Pinus radiata. Tree Physiol. 36, 63-77. https://doi.org/10.1093/treephys/tpv127.

Fahad, S., Bano, A., 2012. Effect of salicylic acid on physiological and biochemica characterization of maize grown in saline area. Pak. J. Bot. 44, 1433-1438.

Fankhauser, C., Christie, J.M., 2015. Plant phototropic growth. Curr. Biol. 25, R384-9. https://doi.org/10.1016/j.cub.2015.03.020.

Fayez, K.A., Bazaid, S.A., 2014. Improving drought and salinity tolerance in barley by application of salicylic acid and potassium nitrate. J. Saudi Soc. Agric. Sci. 13, 45-55. https://doi.org/10.1016/j.jssas.2013.01.001.

Fernández, J.-E., 2014. Understanding olive adaptation to abiotic stresses as a tool to increase crop performance. Environ. Exp. Bot. 103, 158-179. https://doi.org/10. 1016/j.envexpbot.2013.12.003.

Genty, B., Briantais, J.M., Baker, N.R., 1989. The relationship between the quantum yield of photosynthetic electron transport and quenching of chlorophyll fluorescence. Biochim. Biophys. Acta 990, 87-92. https://doi.org/10.1016/S0304-4165(89) 80016-9.

Glenn, D.M., Drake, S., Abbott, J.A., Puterka, G.J., Gundrum, P., 2005. Season and cultivar influence the fruit quality response of apple cultivars to particle film treatments. HortTechnology 15, 249-253.

Hashempour, A., Ghasemnezhad, M., Fotouhi, Ghazvini R., Sohani, M.M., 2014. The physiological and biochemical responses to freezing stress of olive plants treated with salicylic acid. Russ. J. Plant Physiol. 61, 443-450. https://doi.org/10.1134/ S1021443714040098.

Hu, Y., Schmidhalter, U., 2005. Drought and salinity: a comparison of their effects on mineral nutrition of plants. J. Plant Nutr. Soil Sci. (1999) 168, 541-549. https://doi. org/10.1002/jpln.200420516.

IPCC, 2013. Climate Change 2013: the Physical Science Basis. Contribution of Working Group I to the Fifth Assessment Report of the Intergovernmental Panel on Climate Change. IPCC, New York.

IPMA, 2017. Instituto Português Do Mar E Da Atmosfera. acessed on 20 December 2017. http://www.ipma.pt/pt/oclima/normais.clima/.

Irigoyen, J.J., Einerich, D.W., Sánchez-Díaz, M., 1992. Water stress induced changes in concentrations of proline and total soluble sugars in nodulated alfalfa (Medicago sativd) plants. Physiol. Plant. 84, 55-60. https://doi.org/10.1111/j.1399-3054.1992. tb08764.x.

Jain, M., Khurana, J.P., 2009. Transcript profiling reveals diverse roles of auxin-responsive genes during reproductive development and abiotic stress in rice. FEBS J. 276, 3148-3162. https://doi.org/10.1111/j.1742-4658.2009.07033.x.

Jalal, R.S., Moftah, A.E., Bafeel, S.O., 2012. Effect of salicylic acid on soluble sugars, proline and protein patterns of shara (Plectranthus tenuiflorus) plants grown under water stress conditions. Int. Res. J. Agric. Sci. Soil Sci. 2, 400-407.

Jesus, C., Meijón, M., Monteiro, P., Correia, B., Amaral, J., Escandón, M., Cañal, M.J., Pinto, G., 2015. Salicylic acid application modulates physiological and hormonal changes in Eucalyptus globulus under water deficit. Environ. Exp. Bot. 118, 56-66. https://doi.org/10.1016/j.envexpbot.2015.06.004.

Jifon, J.L., Syvertsen, J.P., 2003. Kaolin particle film applications can increase photosynthesis and water use efficiency of 'Ruby Red' grapefruit leaves. J. Am. Soc. Hortic. Sci. 128, 107-112.

Kang, G., Li, G., Xu, W., Peng, X., Han, Q., Zhu, Y., Guo, T., 2012. Proteomics reveals the effects of salicylic acid on growth and tolerance to subsequent drought stress in wheat. J. Proteome Res. 11, 6066-6079. https://doi.org/10.1021/pr300728y.

Khan, M.I.R., Fatma, M., Per, T.S., Anjum, N.A., Khan, N.A., 2015. Salicylic acid-induced abiotic stress tolerance and underlying mechanisms in plants. Front. Plant Sci. 6, 462. https://doi.org/10.3389/fpls.2015.0046.

Klein, B.P., Perry, A.K., 1982. Ascorbic acid and vitamin A activity in selected vegetables from different geographical areas of the United States. J. Food Sci. 47, 941-945. https://doi.org/10.1111/j.1365-2621.1982.tb12750.x.

Krause, G.H., Weis, E., 1991. Chlorophyll fluorescence and photosynthesis: the basics. Annu. Rev. Plant Physiol. Plant Mol. Biol. 42, 313-349. https://doi.org/10.1146/ annurev.pp.42.060191.001525.

Lichtenthaler, H.K., 1987. Chlorophylls and carotenoids: pigments of photosynthetic biomembranes. Meth. Enzymol. 148C, 350-382. https://doi.org/10.1016/00766879(87)48036-1.

Ma, X., Zheng, J., Zhang, X., Hu, Q., Qian, R., 2017. Salicylic acid alleviates the adverse effects of salt stress on Dianthus superbus (Caryophyllaceae) by activating photosynthesis, protecting morphological structure, and enhancing the antioxidant system. Front. Plant Sci. 8, 600. https://doi.org/10.3389/fpls.2017.00600.

Mattos, L.M., Moretti, C.L., 2015. Oxidative stress in plants under drought conditions and the role of different enzymes. Enzym. Eng. 5, 1-6. https://doi.org/10.4172/2329-
6674.1000136

Maxwell, K., Johnson, G.N., 2000. Chlorophyll fluorescence a practical guide. J. Exp. Bot. 51, 659-668. https://doi.org/10.1093/jexbot/51.345.659.

Nanos, P.G., 2015. Leaf and fruit responses to kaolin particle film applied onto mature olive trees. J. Biol. Agric. Healthc. 5, 17-27.

Nazar, R., Umar, S., Khan, N.A., Sareer, O., 2015. Salicylic acid supplementation improves photosynthesis and growth in mustard through changes in proline accumulation and ethylene formation under drought stress. S. Afr. J. Bot. 98, 84-94. https:// doi.org/10.1016/j.sajb.2015.02.005.

Osaki, M., Shinano, T., Tadano, T., 1991. Redistribution of carbon and nitrogen compounds from the shoot to the harvesting organs during maturation in field crops. Soil Sci. Plant Nutr. 37, 117-128. https://doi.org/10.1080/00380768.1991.10415017.

Peleg, Z., Blumwald, E., 2011. Hormone balance and abiotic stress tolerance in crop plants. Curr. Opin. Plant Biol. 14, 290-295. https://doi.org/10.1016/j.pbi.2011.02. 001.

Peng, Y.B., Lu, Y.F., Zhang, D.P., 2003. Abscisic acid activates ATPase in developing apple fruit especially in fruit phloem cells. Plant Cell Environ. 26, 1329-1342. https://doi. org/10.1046/j.1365-3040.2003.01057.x.

Petridis, A., Therios, I., Samouris, G., Koundouras, S., Giannakoula, A., 2012. Effect of water deficit on leaf phenolic composition, gas exchange, oxidative damage and antioxidant activity of four Greek olive (Olea europaea L.) cultivars. Plant Physiol. Biochem. 60, 1-11. https://doi.org/10.1016/j.plaphy.2012.07.014.

Rivas-San Vicente, M., Plasencia, J., 2011. Salicylic acid beyond defence: its role in plant growth and development. J. Exp. Bot. 62, 3321-3338. https://doi.org/10.1093/jxb/ err031.

Rodrigues, M.Â., Ferreira, I.Q., Claro, A.M., Arrobas, M., 2012. Fertilizer recommendations for olive based upon nutrients removed in crop and pruning. Sci. Hortic. 142, 205-211. https://doi.org/10.1016/j.scienta.2012.05.024.

Rosa, M., Prado, C., Podazza, G., Interdonato, R., González, J.A., Hilal, M., Prado, F.E., 2009. Soluble sugars - Metabolism, sensing and abiotic stress: A complex network in the life of plants. Plant Signal. Behav. 4, 388-393 doi: 0.4161/psb.4.5.8294.

Rosati, A., Metcalf, S.G., Buchner, R.P., Fulton, A.E., Lampinen, B.D., 2006. Physiological effects of kaolin applications in well-irrigated and water-stressed walnut and almond trees. Ann. Bot. 98, 267-275. https://doi.org/10.1093/aob/mcl100.

Roussos, P.A., Denaxa, N.-K., Damvakaris, T., Stournaras, V., Argyrokastritis, I., 2010. Effect of alleviating products with different mode of action on physiology and yield of olive under drought. Sci. Hortic. 125, 700-711. https://doi.org/10.1016/j.scienta. 2010.06 .003$.

Sakhabutdinova, A.R., Fatkhutdinova, D.R., Bezrukova, M.V., Shakirova, F.M., 2003 Salicylic acid prevents the damaging action of stress factors on wheat plants. Bulg. J. Plant Physiol. Special Issue 314-319.

Savé, R., Biel, C., de Herralde, F., 2000. Leaf pubescence, water relations and chlorophyll fluorescence in two subspecies of Lotus creticus L. Biol. Plant. 43, 239-244. https:// doi.org/10.1023/A:1002704327076.

Schindelin, J., Arganda-Carreras, I., Frise, E., Kaynig, V., Longair, M., Pietzsch, T., Preibisch, S., Rueden, C., Saalfeld, S., Schmid, B., Tinevez, J.Y., White, D.J., Hartenstein, V., Eliceiri, K., Tomancak, P., Cardona, A., 2012. Fiji: an open-source platform for biological-image analysis. Nat. Methods 9, 676-682. https://doi.org/10. 1038/nmeth.2019.

Segura-Monroy, S., Uribe-Vallejo, A., Ramirez-Godoy, A., Restrepo-Diaz, H., 2015. Effect of kaolin application on growth, water use efficiency, and leaf epidermis characteristics of Physallis peruviana seedlings under two irrigation regimes. J. Agric. Sci. Tech. 17, 1585-1596.

Sesták, Z., Castky, J., Jarvis, P.G., 1971. Plant Photosynthetic Production: Manual of Methods. Dr W. Junk Publishers, The Hague, Netherlands.

Shakirova, F.M., Sakhabutdinova, A.R., Bezrukova, M.V., Fatkhutdinova, R.A., Fatkhutdinova, D.R., 2003. Changes in the hormonal status of wheat seedlings induced by salicylic acid and salinity. Plant Sci. 164, 317-322. https://doi.org/10. 1016/S0168-9452(02)00415-6.

Sharma, E., Sharma, R., Borah, P., Jain, M., Khurana, J.P., 2015. Emerging roles of auxin in abiotic stress responses. In: Pandey, G.K. (Ed.), Elucidation of Abiotic Stress Signaling in Plants: Functional Genomics Perspectives. Springer, New York, pp. 299-328.

Shellie, K., Glenn, D.M., 2008. Wine grape response to foliar particle film under differing levels of preveraison water stress. HortScience 43, 1392-1397.

Shen, C., Bai, Y., Wang, S., Zhang, S., Wu, Y., Chen, M., Jiang, D., Qi, Y., 2010. Expression profile of PIN, AUX/LAX and PGP auxin transporter gene families in Sorghum bicolor under phytohormone and abiotic stress. FEBS J. 277, 2954-2969. https://doi.org/10. 1111/j.1742-4658.2010.07706.x.

Shojaie, B., Mostajeran, A., Esmaeili, A., 2015. Different drought conditions could modulate growth responses of Arabidopsis thaliana through regulation of mRNA expression of genes encoding plasma membrane PIN proteins Int. Int. J. Adv. Res. Biol. Sci. 2, 241-254.

Singleton, V.L., Rossi, J.A., 1965. Colorimetry of total phenolics with phosphomolybdicphosphotungstic acid reagents. Am. J. Enol. Vitic. 16, 144-158.

von Caemmerer, S., Farquhar, G.D., 1981. Some relationships between the biochemistry of photosynthesis and the gas exchange of leaves. Planta 153, 376-387. https://doi. org/10.1007/BF00384257.

Walinga, I., van Vark, W., Houba, V., van der Lee, J., 1989. Soil and Plant Analysis: Part 7 - Plant Analysis Procedures. Wageningen Agricultural University, The Netherlands.

Wang, C., Yang, A., Yin, H., Zhang, J., 2008. Influence of water stress on endogenous hormone contents and cell damage of maize seedlings. J. Integr. Plant Biol. 50, 427-434. https://doi.org/10.1111/j.1774-7909.2008.00638.x.

Wang, Y., Zhang, H., Hou, P., Su, X., Zhao, P., Zhao, H., Liu, S., 2014. Foliar-applied salicylic acid alleviates heat and high light stress induced photoinhibition in wheat (Triticum aestivum) during the grain filling stage by modulating the psbA gene 
transcription and antioxidant defense. Plant Growth Regul. 73, 289-297. https://doi. org/10.1007/s10725-014-9889-9.

Wani, S.H., Kumar, V., Shriram, V., Sah, S.K., 2016. Phytohormones and their metabolic engineering for abiotic stress tolerance in crop plants. Crop J. 4, 162-176. https:// doi.org/10.1016/j.cj.2016.01.010.

Xu, B.J., Chang, S.K., 2007. A comparative study on phenolic profiles and antioxidant activities of legumes as affected by extraction solvents. J. Food Sci. 72, S159-66. https://doi.org/10.1111/j.1750-3841.2006.00260.x.

Yildirim, E., Turan, M., Guvenc, I., 2008. Effect of foliar salicylic acid applications on growth, chlorophyll, and mineral content of cucumber grown under salt stress. J.
Plant Nutr. 31, 593-612. https://doi.org/10.1080/01904160801895118.

Zhang, D., Du, Q., Zhang, Z., Jiao, X., Song, X., Li, J., 2017. Vapour pressure deficit control in relation to water transport and water productivity in greenhouse tomato production during summer. Sci. Rep. 7, 43461. https://doi.org/10.1038/srep43461. Zheng, Z., Guo, Y., Novák, O., Chen, W., Ljung, K., Noel, J.P., Chory, J., 2016. Local auxin metabolism regulates environment-induced hypocotyl elongation. Nat. Plants 2https://doi.org/10.1038/nplants.2016.25. 16025-16025.

Zhishen, J., Mengcheng, T., Jianming, W., 1999. The determination of flavonoid contents in mulberry and their scavenging effects on superoxide radicals. Food Chem. 64, 555-559. https://doi.org/10.1016/S0308-8146(98)00102-2. 